\title{
PURIFICATION AND PARTIAL CHARACTERIZATION OF PHOSPHOLIPASES A 2 FROM Bothrops asper (BARBA AMARILLA) SNAKE VENOM FROM CHIRIGUANÁ (CESAR, COLOMBIA)
}

\section{RAMÍREZ-AVILA J. ${ }^{1}$, QUEVEDO B. E. ${ }^{2}$, LÓPEZ E. ${ }^{3}$, RENJIFO J. M. ${ }^{1}$}

\begin{abstract}
${ }^{1}$ Serum Group, National Institute of Health (INS), Bogotá, Colombia, South America; ${ }^{2}$ Faculty of Engineering, National University of Colombia, Bogotá, Colombia, South America; ${ }^{3}$ Department of Chemistry, Faculty of Sciences, National University of Colombia, Bogotá, Colombia, South America.
\end{abstract}

ABSTRACT. Components with phospholipase $\mathrm{A}_{2}$ activity were isolated by gel filtration and cationic exchange chromatography from the venom of Bothrops asper snakes from Chiriguaná, Colombia $\left(9^{\circ} 22^{\prime} \mathrm{N} ; 73^{\circ} 37^{\prime} \mathrm{W}\right)$. Five fractions were obtained by the gel filtration, and $\mathrm{PLA}_{2}$ activity was found in fraction 3 (F3). In the cationic exchange chromatography, F3 showed eight components with $\mathrm{PLA}_{2}$ activity. Six of these components appeared as one band in polyacrylamide gel electrophoresis (SDS-PAGE). Fractions II and VII exhibited an optimal activity at $\mathrm{pH} 9$ and $52^{\circ} \mathrm{C}$. The optimum calcium concentration for fraction II was $48 \mathrm{mM}$ and for fraction VII, $384 \mathrm{mM}$. Both fractions showed thermal stability. Fraction II was stable at $\mathrm{pH}$ values between 2.5 and 9, and fraction VII, between 2.5 and 8. The Michaelis Menten constant $\left(\mathrm{K}_{\mathrm{M}}\right)$ was $3.5 \times 10^{-3} \mathrm{M}$ for fraction II and $1.6 \times 10^{-3} \mathrm{M}$ for fraction VII. The molecular weight was 16,000 Dalton for fraction II and 17,000 Dalton for fraction VII. Both isoenzymes did not show any toxic activity $\left(\mathrm{DL}_{50}\right)$ at 5.3 and $4 \mu \mathrm{g} / \mathrm{g}$. The two fractions showed different kinetic constant $\left(\mathrm{K}_{\mathrm{M}}\right)$, calcium requirement, and substrate specificity for haemolytic activity.

KEY WORDS: phospholipase, isoenzymes, snake, venom, Bothrops asper, Colombia

CORRESPONDENCE TO: J. Ramírez-Avila, Avenida calle 26, N 51-60, Bogotá, D. C., Colombia, South America. Phone: (571) 220-77-00, Ext. 485. Fax: (571) 222-34-68.

Email: jramirezavila61@yahoo.com 


\section{INTRODUCTION}

Phospholipases $\mathrm{A}_{2}\left(\mathrm{PLA}_{2} \mathrm{~s}\right)$ (EC.3.1.1.4) catalyzes the hydrolysis of the 2-acyl ester linkage of 1,2-diacyl-3-sn-phosphoglycerides, with $\mathrm{Ca}^{2+}$ requirement $(20,25)$. These enzymes play an important role in the lipid metabolism, and have been widely used to study the structure of lipoproteins (1) among other applications.

Snake venoms are particularly rich in $\operatorname{PLA}_{2} \mathrm{~S}(5,12,15,22)$ and some of them contain more than one isoform of this enzyme. Many of these isoenzymes have similar molecular weights but can be differentiated in a small number of amino acids $(9,20)$ by ion-exchange chromatography $(14,15,26)$ or isoelectric focusing $(23)$. Snake venom PLA $_{2} \mathrm{~S}$ are able to induce several biological effects, such as pre-synaptic or post-synaptic neurotoxicity, cardiotoxicity, myotoxicity, platelet aggregation, oedema formation, haemolysis, anticoagulation, convulsion, and hypotension (26). This diversity of physiological functions of $\mathrm{PLA}_{2} \mathrm{~S}$ isoenzymes from snake venoms is very important for the production of antivenoms and to understand the accelerated evolution of this enzyme in the Viperidae venom $(19,20)$. Therefore, it is also very important to identify the diversity of isoforms present in the same species and in different populations.

In Colombia, snakes of the Bothrops genus have medical importance since they are responsible for more than $90 \%$ of the total snakebites (unpublished information from INS). Bothrops asper (Family Viperidae, Subfamily Crotalinae) is the only species of that genus found in northern Colombia. It is poorly differentiated from Bothrops atrox, and there is a great controversy upon the taxonomic status of these two species (2). Snakes of the Bothrops genus from northern Colombia are classified as B. asper, based on the data published by Campbell and Lamar (2).

In the present study, we report the isolation and partial characterization of snake venom fractions with phospholipases $\mathrm{A}_{2}$ activity from $B$. asper snakes from Chiriguaná (Cesar), northern Colombia. 
J. Ramírez-Avila et al. PURIFICATION AND PARTIAL CHARACTERIZATION OF PHOSPHOLIPASES A 2 FROM Bothrops asper (BARBA AMARILLA) SNAKE VENOM FROM CHIRIGUANÁ (CESAR, COLOMBIA). J. Venom. Anim. Toxins incl. Trop. Dis., 2004, 10, 3, p.244.

\section{MATERIALS AND METHODS}

\section{Venom}

B. asper venom was obtained from several specimens collected in Chiriguaná (Cesar, Colombia). Venom was filtered, lyophilized and stored at $-20^{\circ} \mathrm{C}$ in the venom bank of the Instituto Nacional de Salud, Bogotá, D. C., Colombia.

\section{Isolation of phospholipase $\mathrm{A}_{2}$}

Crude venom (100 mg) was dissolved in $1 \mathrm{ml}$ of $5 \%$ acetic acid, cleared by centrifugation for 30 minutes at $1,800 \mathrm{~g}$, submitted to gel filtration on Sephadex G-75 (Pharmacia LKB, Sweden) column $(2.6 \times 71.5 \mathrm{~cm})$, and then, eluted with the same solvent. Fractions of $10 \mathrm{ml}$ were collected at a flow rate of $60 \mathrm{ml} / \mathrm{h}$ using a Frac-200 fraction collector (Pharmacia LKB). F3 with $\mathrm{PLA}_{2}$ activity was taken up from the gel filtration and applied to a Sephadex G-25 (Pharmacia LKB) column $(1.6 \times 14.5 \mathrm{~cm})$ previously equilibrated, and then, eluted with 10 $\mathrm{mM}$ of acetic acid, $\mathrm{pH} 5$.

F3 in $10 \mathrm{mM}$ of acetic acid, pH 5 was applied to ion-exchange chromatography on a MONO S (HR 5/5) column (Pharmacia LKB), which had been previously equilibrated with a similar solvent. The elution used a constant concentration gradient, from 0 to $1 \mathrm{M}$ of $\mathrm{NaCl}$ with the same solvent. Fractions of $1 \mathrm{ml}$ were collected at $60 \mathrm{ml} / \mathrm{h}$. The separation was done on FPLC (Pharmacia LKB); the absorbances at $280 \mathrm{~nm}$, conductivities and collected fractions were monitored. The resulting eight peaks were collected, pooled, and dialyzed using membranes (Spectra/Por 1) with a molecular weight of 6,000-8,000 Da, and later lyophilized. An aliquot of dialyzed fractions was used for the determination of protein concentration by the Lowry method (13).

\section{Polyacrylamide gel electrophoresis (SDS-PAGE)}

Gel for SDS-PAGE was prepared and run using a Hoeffer minigel electrophoresis system. Electrophoresis was performed in presence of sodium dodecyl sulfate (SDS) in $0.75 \mathrm{~mm}$ thick slab gels, according to the Laemmli method (10). The gels were silver stained (17). The mobility of standard proteins $(14.4-94 \mathrm{KDa})$ and molecular weights of the samples were analysed using the Kodak Digital Science 1D Image Analysis Software (4). 
J. Ramírez-Avila et al. PURIFICATION AND PARTIAL CHARACTERIZATION OF PHOSPHOLIPASES A 2 FROM Bothrops asper (BARBA AMARILLA) SNAKE VENOM FROM CHIRIGUANÁ (CESAR, COLOMBIA). J. Venom. Anim. Toxins incl. Trop. Dis., 2004, 10, 3, p.245.

\section{Lethality assays}

Lethality assays were performed with ICR male mice (16-18 g) by intraperitoneal (i.p). injection with $0.2 \mathrm{ml}$ of the tested solution. The $\mathrm{LD}_{50}$ was evaluated 48 hours after the injection (21).

\section{Phospholipase $\mathrm{A}_{2}$ activity}

Phospholipase $A_{2}$ activity was assayed by three procedures. The first one was the indirect haemolytic method, an adaptation of the procedures of Habermann and Hardt (8), and Gene et al. (6); the second was the potentiometric titration (16), and the third, the colorimetric assay with phenol red (11).

The substrate for the indirect haemolysis was prepared with $0.68 \mathrm{~g}$ of agarose A dissolved in $66.5 \mathrm{ml}$ of $50 \mathrm{mM}$ phosphate buffer, $\mathrm{pH} 7.5$, in boiling water bath. The solution was cooled to $52^{\circ} \mathrm{C}$, mixed with $1.2 \mathrm{ml}$ of $10 \mathrm{mM} \mathrm{CaCl}_{2}, 16.5 \mathrm{ml}$ of $3.5 \mathrm{mM}$ egg lecithin, and $1.2 \mathrm{ml}$ of lamb erythrocytes, and poured into a glass plate $(15.4 \mathrm{X} 17.6 \mathrm{~cm})$ previously heated to $52^{\circ} \mathrm{C}$. After layer consolidation, cylindrical holes $(2.5 \mathrm{~mm})$ were punched. Each hole was filled with $10 \mu 1$ of enzyme solution and incubated for 20 hours at $37^{\circ} \mathrm{C}$. During incubation, the enzyme diffused into the gel and cleared the erythrocyte by haemolysis, forming a halo. The diameter of these areas was measured in millimetres $(\mathrm{mm})$.

Indirect haemolysis assay was used to identify the presence of phospholipase $A_{2}$ in venom fractionation and determine its thermal and $\mathrm{pH}$ stability. Thermal stability was studied from 6 to $92^{\circ} \mathrm{C}$; the enzymatic solution was incubated for 30 minutes, cooled in an ice bath for 5 minutes, and the residual activity was assayed.

The assays for $\mathrm{pH}$ stability were performed at $\mathrm{pH}$ values ranging from 2.5 to 11.3; the enzymatic solution was placed in a different buffer for 19 hours at room temperature $\left(18^{\circ} \mathrm{C}\right)$, and the residual activity was assayed.

The potentiometric titration method was used to quantify $\mathrm{PLA}_{2}$ activity in the enzyme isolation process and in the determination of optimal $\mathrm{pH}$ and temperature, using an egg yolk suspension. The same procedure was used for the determination of the optimal concentration of $\mathrm{Ca}^{2+}$ and the Michaelis Menten constant $\left(\mathrm{K}_{\mathrm{M}}\right)$, but this time, phosphatidylcholine (Merck) 
J. Ramírez-Avila et al. PURIFICATION AND PARTIAL CHARACTERIZATION OF PHOSPHOLIPASES A 2 FROM Bothrops asper (BARBA AMARILLA) SNAKE VENOM FROM CHIRIGUANÁ (CESAR, COLOMBIA). J. Venom. Anim. Toxins incl. Trop. Dis., 2004, 10, 3, p.246.

was used instead of egg yolk. One unit of enzymatic activity was defined as the release of 1.0 meq of fatty acid per min. Specific activity corresponds to the number of meq of fatty acid liberated per min per mg of protein.

Colorimetric assay was used in order to determine substrate specificity (phosphatidylcholine, PC; phosphatidylethanolamine, PE; phosphatidylinositol, PD; sphingomyelin, SG; and cardiolipin, CP). The different substrates were prepared, as described by Lobo de Araujo and Radvanyi (11), to a final concentration of $0.27 \%(\mathrm{~W} / \mathrm{V})$. One unit of enzymatic activity was defined as absorbance decrease of 0.01 per min.

\section{RESULTS}

Eight fractions of $B$. asper venom with phospholipase $A_{2}$ activity were isolated in a two-step purification procedure. First, the venom was separated by molecular weight on Sephadex G75 into five fractions (Figure 1); then, the fraction containing phospholipase activity (F3) was chromatographied on MONO S (HR5/5) resulting in eight fractions with phospholipase activity (Figure 2). Table 1 presents the recovery of protein and activity of all fractions obtained from the two-step purification procedure. F3, resulting from the first step, accounted for $33 \%$ of the venom protein, and the isoenzymes FII and FVII accounted for $10.8 \%$ and $8.0 \%$ of the protein bounded to the column. PAGE of F3 from the first step purification procedure showed two bands of 16.2 and 17.2 KDa (Figure 3A); the isoenzymes resulting from the cation-exchange chromatography migrated as a single band in SDS-PAGE, and their molecular weights were from 16 to $17 \mathrm{KDa}$ (Figure 3B). These two fractions were the most interesting since they had more $\mathrm{PLA}_{2}$ activity and protein.

The optimal pH for the FI and FII isoenzymes was 9, and for FVII, 9-10 (Figure 4A), and the optimal temperature was $52^{\circ} \mathrm{C}$ for the three fractions (Figure 4B). The optimal concentration of $\mathrm{Ca}^{2+}$ for the FII isoenzyme was $48 \mathrm{mM}$, and for the FVII isoenzyme, it was $384 \mathrm{mM}$. FII and FVII showed thermal stability at all the temperatures studied for 30 minutes, and at $92^{\circ} \mathrm{C}$ for 60 minutes. The FII isoenzyme was stable at $\mathrm{pH}$ values ranging from 2.5 to 9 , and FVII isoenzyme, from 2.5 to 8 . 
J. Ramírez-Avila et al. PURIFICATION AND PARTIAL CHARACTERIZATION OF PHOSPHOLIPASES A 2 FROM Bothrops asper (BARBA AMARILLA) SNAKE VENOM FROM CHIRIGUANÁ (CESAR, COLOMBIA). J. Venom. Anim. Toxins incl. Trop. Dis., 2004, 10, 3, p.247.

The Michaelis Menten constant $\left(\mathrm{K}_{\mathrm{M}}\right)$ for the FII isoenzyme was $3.5 \times 10^{-3} \mathrm{M}$, and for the FVII isoenzyme, it was $1.6 \times 10^{-3} \mathrm{M}$ (Figure 5). Kinetic data were analysed by a non-linear model using the SYSTAT program. The assay of substrate specificity showed the following order: $\mathrm{PC}>\mathrm{PD}>\mathrm{CP}>\mathrm{SG}>\mathrm{PE}$ for the FII and FVII isoenzymes. Evaluation of substrate specificity by the potentiometer method showed no reaction with lysolecithin, confirming that the isolated enzymes were phospholipases $\mathrm{A}_{2}\left(\mathrm{PLA}_{2} \mathrm{~s}\right)$. The FII and FVII isoenzymes did not show any lethal activity in a dose of 96 and $71.4 \mu \mathrm{g}$ per $16-18 \mathrm{~g}$ mouse.

\section{DISCUSSION}

The specific activity of $\mathrm{PLA}_{2}$ found in the venom of B. asper from Chiriguaná was $0.05 \mathrm{U} / \mathrm{mg}$ of protein, similar to other venoms of the Bothrops genus $(0.02 \mathrm{mM}$ of fatty acid $/ \mathrm{min} / \mathrm{mg})$ and to $N$. naja venom, which is $0.08 \mathrm{mM}$ of fatty acid/min/mg (12).

The procedure described above for isolation of different fractions with $\mathrm{PLA}_{2}$ activity from the B. asper venom is simple, quick, and efficient. The first step of purification on gel-filtration chromatography using 5\% of acetic acid facilitated the elution of $\mathrm{PLA}_{2}$ into one fraction (F3). The total activity of this fraction was $6.12 \mathrm{U}$, which presented a twofold increase in the activity in crude venom (3.52 U), as showed in $\mathrm{PLA}_{2}$ from Bothrops insularis (3). F3 represents $33 \%$ of the crude venom protein, and has a specific activity of $0.28 \mathrm{U} / \mathrm{mg}$ protein, with a purity factor of 5.28. In other venoms from Bothrops snakes, such as B. insularis (3), it was found that $6 \%$ of the venom protein was $\mathrm{PLA}_{2}$, and for Bothrops lanceolatus alone, $2 \%$ was $\mathrm{PLA}_{2}$ (12). The results showed that in $B$. asper venom, the proportion of $\mathrm{PLA}_{2}$ is high.

The step of cationic-exchange chromatography using $10 \mathrm{mM}$ of acetic acid facilitated the elution of the eight fractions with $\mathrm{PLA}_{2}$ from B. asper venom, and showed the multiple forms of $\mathrm{PLA}_{2} \mathrm{~S}$ present in snake venoms $(12,15,23)$. The isoenzymes found in $B$. asper were not dimeric forms, as in other venoms $(20,30)$; however, the same bands are observed in electrophoresis under non-reducing conditions. $\mathrm{PLA}_{2} \mathrm{~S}$ isolated from B. atrox (15) and Bothrops n. nummifer (30) were found in the monomeric state, suggested to be the common state of $\mathrm{PLA}_{2}$ present in Bothrops venoms. 
J. Ramírez-Avila et al. PURIFICATION AND PARTIAL CHARACTERIZATION OF PHOSPHOLIPASES A 2 FROM Bothrops asper (BARBA AMARILLA) SNAKE VENOM FROM CHIRIGUANÁ (CESAR, COLOMBIA). J. Venom. Anim. Toxins incl. Trop. Dis., 2004, 10, 3, p.248.

All isoenzymes showed one band in electrophoresis with a molecular weight of $17 \mathrm{KDa}$, except for FVII and FVIII (16 KDa). For B. atrox (15) and B. n. nummifer (30), the PLA $2 \mathrm{~S}$ had a molecular weight of $14 \mathrm{KDa}$, and for B. lanceolatus (12), this weight was $15 \mathrm{KDa}$. Cogo et al. (3) found 4 polypeptide chains between 14 and $17 \mathrm{KDa}$ in the $\mathrm{PLA}_{2}$ fraction from B. insularis venom. Gutiérrez and Lomonte (7) summarized the molecular weights found for many myotoxic $\mathrm{PLA}_{2} \mathrm{~s}$ from 10.7 to $16 \mathrm{KDa}$, in which differences can be observed depending on the procedure used for the determination. In SDS-PAGE, the molecular weights of some myotoxic PLA $\mathrm{P}_{2} \mathrm{~S}$ were found between 15 and $16 \mathrm{KDa}$, very close to the values determined for all the $\mathrm{PLA}_{2}$ fractions isolated in this study.

The optimal $\mathrm{pH}$ value for the FI, FII and FVII isoenzymes was 9 , at $25^{\circ} \mathrm{C}$, very close to those related as generic for the $\mathrm{PLA}_{2}$ enzymes isolated from other snake venoms (7.5 and 8.5) (9). The activity is completely inhibited at pH 6 and 12. Salach et al. (24) found 6 isoenzymes in $N$. naja venom with optimum $\mathrm{pH}(7.9$ to 8.0$)$ at $25^{\circ} \mathrm{C}$, and no significant difference was observed, except for IIC. This difference may be related to the enzyme conformational change by $\mathrm{pH}$, as shown by Viljoen et al. (28).

The optimal temperature was different for 3 isoenzymes (FI, FII and FVII), and the maximum temperature was $52^{\circ} \mathrm{C}$. The activities of these three isoenzymes decreased between $10^{\circ} \mathrm{C}$ and $22^{\circ} \mathrm{C}$, and were completely eliminated at $72^{\circ} \mathrm{C}$. Nair et al. (18) studied the optimal PLA 2 temperatures for different total snake venoms, and found that the venom of several Naja species (Elapidae) showed their maximum activity at $65^{\circ} \mathrm{C}$. In the Viperidae family, Agkistrodon piscivorus, Bitis gabonica, and Echis carinatus have their maximum activity at $65^{\circ} \mathrm{C}, 55^{\circ} \mathrm{C}$, and $50^{\circ} \mathrm{C}$, respectively. Besides, several species of Crotalus have their maximum activity at $45^{\circ} \mathrm{C}$. For Trimeresurus flavoviridis venom, it was found that the optimal temperatures for the three isoenzymes were $40^{\circ} \mathrm{C}, 45^{\circ} \mathrm{C}$, and $\geq 75^{\circ} \mathrm{C}(29)$.

Determination of the optimal concentration of $\mathrm{Ca}^{2+}$ showed an absolute dependence of this ion for two of the isoenzymes studied (FII and FVII). Using $4 \mathrm{mM}$ of phosphatidylcholine as substrate at $\mathrm{pH} 9$ and $52^{\circ} \mathrm{C}$, the FII isoenzyme presented maximum activity with $48 \mathrm{mM}$ of $\mathrm{Ca}^{2+}$, while FVII required $348 \mathrm{mM}$. These differences in the concentration of $\mathrm{Ca}^{2+}$ are probably related to the enzyme conformational change produced by this divalent ion (5). 
J. Ramírez-Avila et al. PURIFICATION AND PARTIAL CHARACTERIZATION OF PHOSPHOLIPASES A 2 FROM Bothrops asper (BARBA AMARILLA) SNAKE VENOM FROM CHIRIGUANÁ (CESAR, COLOMBIA). J. Venom. Anim. Toxins incl. Trop. Dis., 2004, 10, 3, p.249.

FVII isoenzyme showed high activity with phosphatidylcholine from egg yolk, in contrast to FI, FII and FVIII assayed by the haemolytic method (results not shown). When egg yolk was used as substrate in the same method, the maximum activity corresponded to the FI and FII isoenzymes, progressively decreasing in the other fractions (Figure 2). These results suggest that one of the differences between the 8 fractions is their substrate specificity, being FVII highly specific to egg yolk phosphatidylcholine. However, the specific substrate for the FII and FVII isoforms from B. asper was: $\mathrm{PC}>\mathrm{PD}>\mathrm{CP}>\mathrm{SG}>\mathrm{PE}$, being this order different in $\mathrm{PLA}_{2} \mathrm{~S}$ isolated from other venoms. In $T$. flavoviridis, the order was $\mathrm{PC}>\mathrm{PE}>\mathrm{Pserina} \geq \mathrm{PD}=0$ for three of the isolated isoenzymes (29). The FII and FVII activity on sphingomyelin (SG) was interesting since that substrate is normally resistant to the action of Phospholipase $\mathrm{A}_{2}$ from several fountains $(24,27)$.

The kinetics constant $\left(\mathrm{K}_{\mathrm{M}}\right)$ showed different responses for the FII and FVII isoenzymes. FII presented a typical behavior (5), but needed a critical micelle concentration of the substrate $(\mathrm{cmc}=1 \mathrm{mM})$ to initiate its catalytic activity. On the other hand, FVII could act on monomeric substrates, what suggests that there is not a universal kinetic model for phospholipases or enzymes with the same origin (6).

The Michaelis Menten constant was $3.5 \times 10^{-3}$ and $1.6 \times 10^{-3} \mathrm{mM}$ for the FII and FVII isoenzymes, respectively. These $\mathrm{K}_{\mathrm{M}}$ values are different in $\mathrm{PLA}_{2} \mathrm{~S}$ isolated from other snake venoms, and were determined using phosphatidylcholine from egg yolk as substrate in the watery media. The $\mathrm{K}_{\mathrm{M}}$ value for the $\mathrm{PLA}_{2}$ isolated from C. atrox venom was $7 \times 10^{-3} \mathrm{M}$, using phosphatidylcholine as substrate in the media with diethyl ether (9). For three PLA 2 isoenzymes from $T$. flavoviridis venom, $\mathrm{K}_{\mathrm{M}}$ values were $2.8 \times 10^{-6} \mathrm{M}, 4.3 \times 10^{-6} \mathrm{M}$, and $2.2 \times 10^{-6}$ M, using phosphatidylcholine as substrate in the watery media (29).

The two isoenzymes studied did not present any lethal activity for 90 and $71 \mu \mathrm{g}$ doses when injected intraperitonially into mice between 16 and $18 \mathrm{~g}(5.3 \mu \mathrm{g} / \mathrm{g}$ and $4 \mu \mathrm{g} / \mathrm{g})$, and the crude venom presented lethal activity for $58 \mu \mathrm{g}$. An acid phospholipase $A_{2}$, isolated from $B$. lanceolatus venom, was not toxic when $300 \mu \mathrm{g}$ were injected into mice (12). 
J. Ramírez-Avila et al. PURIFICATION AND PARTIAL CHARACTERIZATION OF PHOSPHOLIPASES A 2 FROM Bothrops asper (BARBA AMARILLA) SNAKE VENOM FROM CHIRIGUANÁ (CESAR, COLOMBIA). J. Venom. Anim. Toxins incl. Trop. Dis., 2004, 10, 3, p.250.

Table 1. Summary of the purification of $\mathrm{PLA}_{2}$ enzymes from B. asper venom.

\begin{tabular}{|c|c|c|c|c|c|}
\hline Step & $\begin{array}{c}\text { Volume } \\
\text { (ml) }\end{array}$ & $\begin{array}{c}\text { Protein* } \\
\text { (mg) }\end{array}$ & $\begin{array}{l}\text { Activity** } \\
\text { (U) }\end{array}$ & $\begin{array}{c}\text { Specific } \\
\text { Activity } \\
\text { (U/mg) }\end{array}$ & Purity Factor \\
\hline Venom & 1.00 & 66.00 & 3.52 & 0.053 & 1.00 \\
\hline \multicolumn{6}{|l|}{ Sephadex G-75 } \\
\hline $\mathrm{F} 1$ & 30.50 & 9.52 & 0.00 & 0.000 & 0.00 \\
\hline $\mathrm{F} 2$ & 65.50 & 14.41 & 0.66 & 0.046 & 0.87 \\
\hline F3 & 90.00 & 21.85 & 6.12 & 0.280 & 5.28 \\
\hline $\mathrm{F} 4$ & 47.00 & 3.67 & 0.00 & 0.000 & 0.00 \\
\hline F5 & 71.00 & 9.19 & 0.00 & 0.000 & 0.00 \\
\hline TOTAL & 304.00 & 58.64 & 6.78 & & \\
\hline
\end{tabular}

Mono S

\begin{tabular}{cccccc} 
Fraction F3 *** & 85.00 & 8.50 & 2.64 & 0.311 & 5.87 \\
FI & 1.00 & 0.07 & 0.12 & 1.714 & 32.34 \\
FII & 6.20 & 0.92 & 1.04 & 1.130 & 21.32 \\
FIII & 1.54 & 0.10 & 0.10 & 1.000 & 18.87 \\
FIV & 3.90 & 0.32 & 0.28 & 0.875 & 16.51 \\
FV & 3.50 & 0.16 & 0.18 & 1.125 & 21.23 \\
FVI & 3.40 & 0.11 & 0.14 & 1.273 & 24.02 \\
FVII & 4.00 & 0.68 & 0.40 & 0.588 & 11.09 \\
FVIII & 11.50 & 5.06 & 0.14 & 0.028 & 0.53 \\
TOTAL & 35.04 & 7.42 & 2.40 & & \\
\hline
\end{tabular}

* Concentration of protein was estimated by the Lowry et al. method (13).

** The activity of $\mathrm{PLA}_{2}$ was assayed by the titration method (16), using egg yolk in sodium deoxycholate. A unit of $\mathrm{PLA}_{2}$ enzymatic activity was defined as the quantity of enzyme that releases a meq of fatty acid per minute.

*** $85 \mathrm{ml}$ of F3 after passing through the Sephadex G-25 column for the buffer change. 


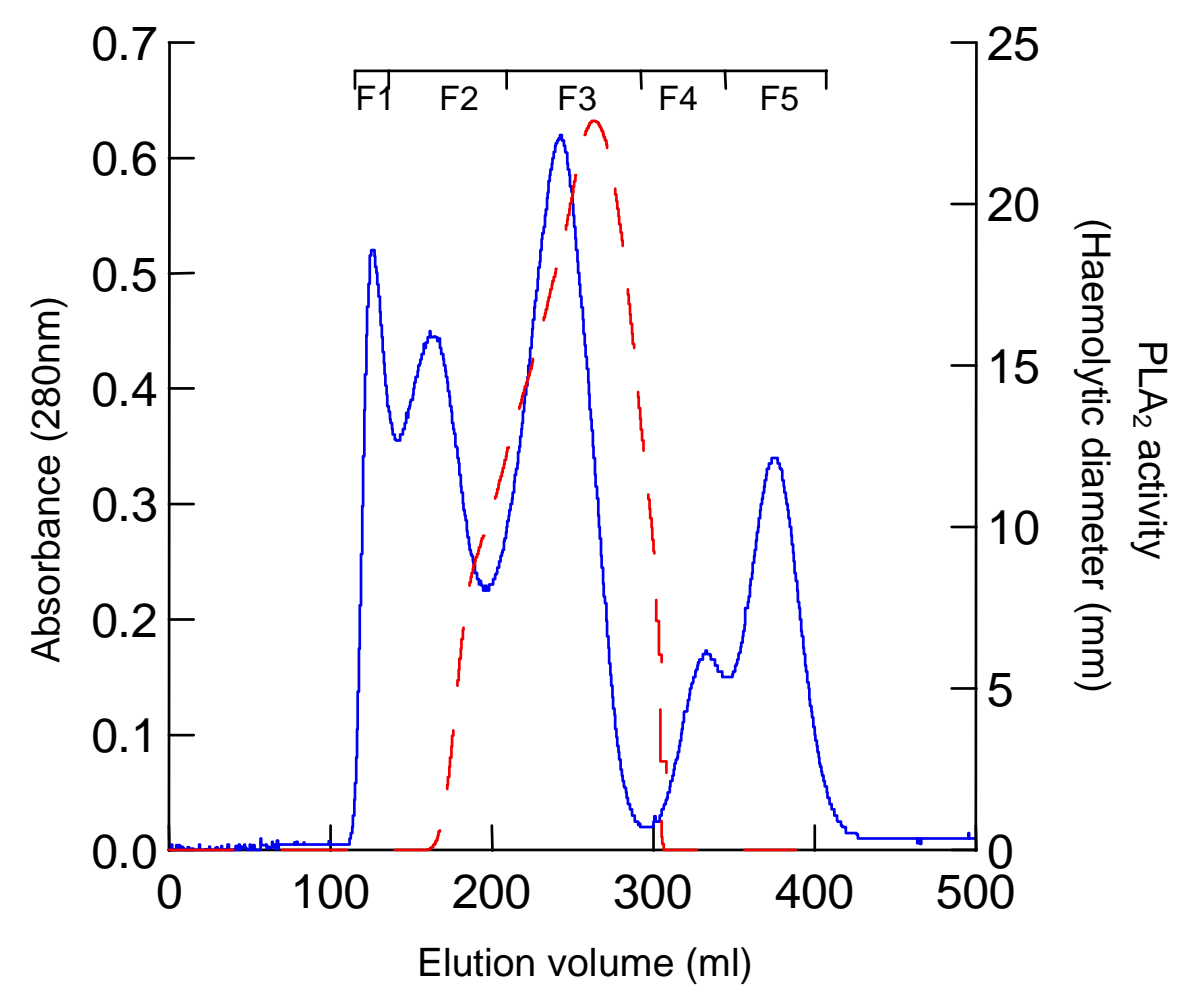

Figure 1. Sephadex G-75 Column Chromatography of B. asper venom.

$100 \mathrm{mg}$ dry weight (66 mg of protein) of B. asper venom was applied to a Sephadex G-75 column $(2.6 \times 71.5 \mathrm{~cm})$ equilibrated with $5 \%$ of acetic acid. The elution was carried out to 60 $\mathrm{ml} / \mathrm{h}$ with the same solvent and collection fractions of $10 \mathrm{ml}$. The absorbance was monitored at $280 \mathrm{~nm}(-)$, and $\mathrm{PLA}_{2}$ activity was assayed by indirect haemolysis $(--)$ using egg yolk in saline solution $(0.85 \%)$. 


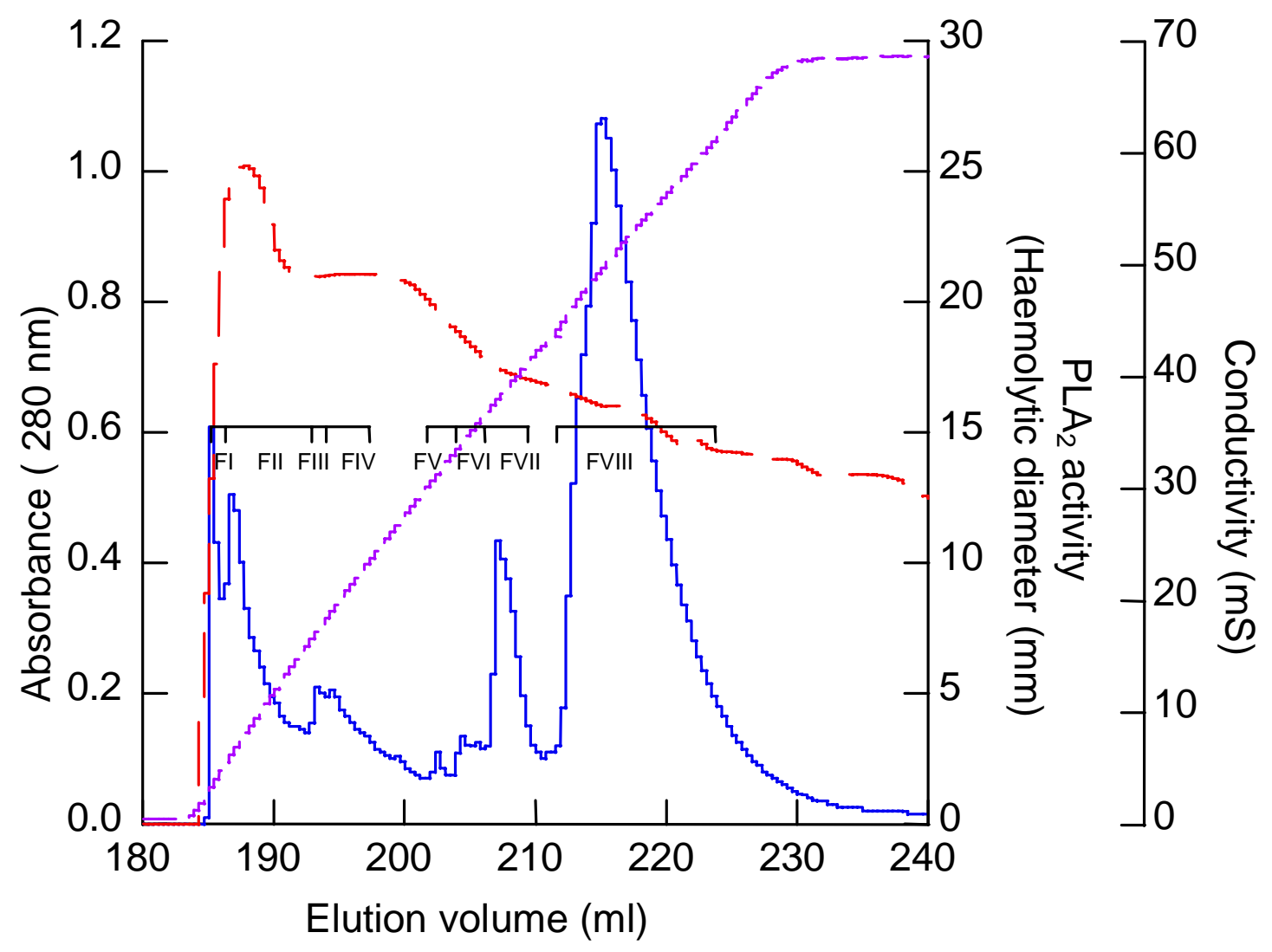

Figure 2. Cation-exchange chromatography on mono $\mathrm{S}$ of the fraction 3 from Sephadex G-75.

$8.5 \mathrm{mg}$ of protein of the fraction 3 (F3) from Sephadex G-75 were applied to the Mono S column (HR 5/5) equilibrated with $10 \mathrm{mM}$ of acetic acid, $\mathrm{pH} 5$, at $60 \mathrm{ml} / \mathrm{h}$ and collection fractions of $1 \mathrm{ml}$. The absorbance was monitored at $280 \mathrm{~nm}(-)$; the elution was carried out in a linear gradient of $\mathrm{NaCl}$ concentration from 0 to $1 \mathrm{M}$, and measured by a conductivity monitor (...-$), \mathrm{PLA}_{2}$ activity was assayed by indirect haemolysis (---), using egg yolk in saline solution $(0.85 \%)$. 

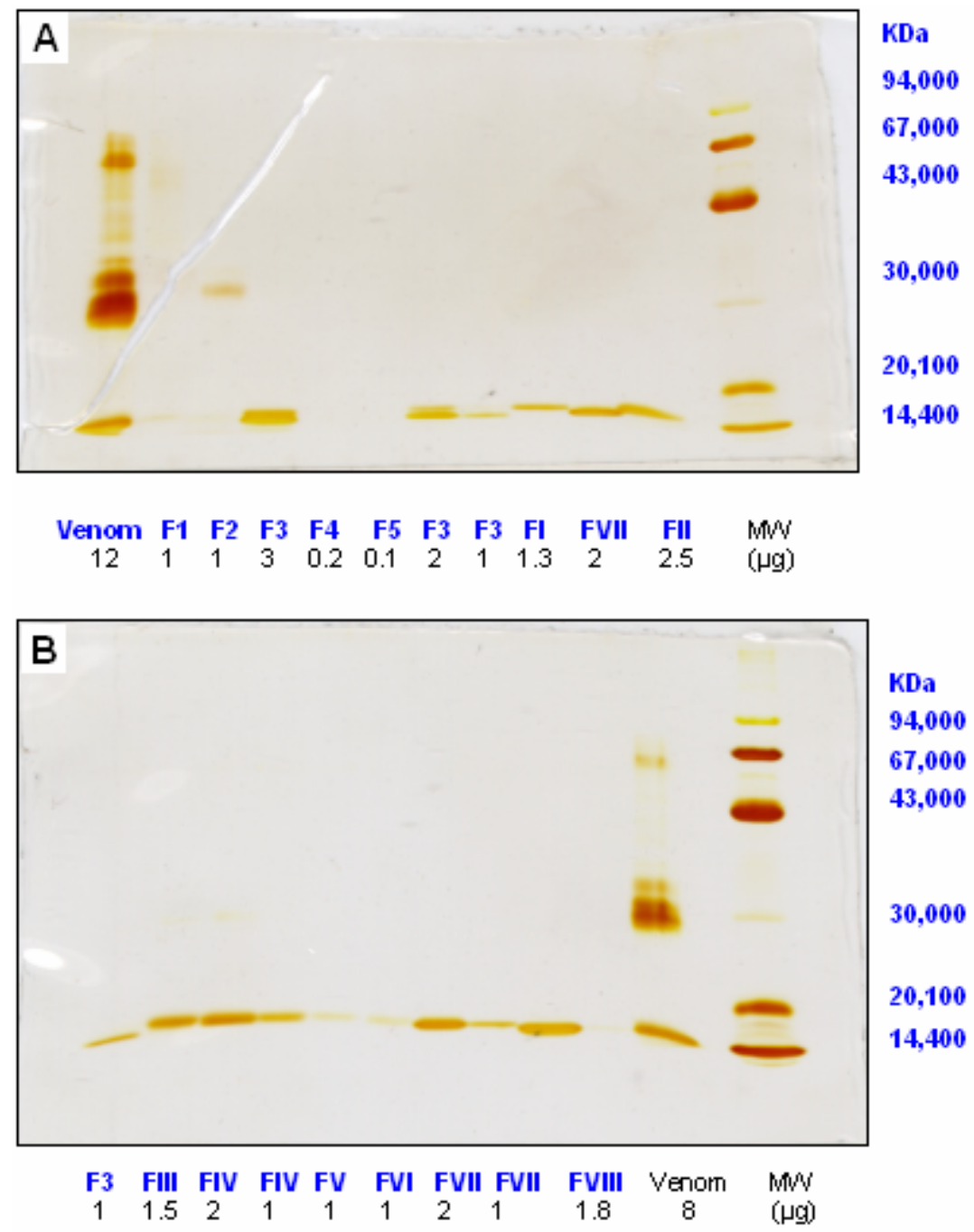

Figure 3. Electrophoresis of the fractions obtained in the isolation of $\mathrm{PLA}_{2}$ from Bothrops asper snake venom.

Polyacrylamide gel of the PLA 2 isolated fractions, in presence of SDS (4\%), $\beta$-mercaptoethanol (2\%), and nitrate of silver stain. The proteins used as standards were: Phosphorylase B $(94,000)$, Albumin (67,000), Ovalbumin (43,000), Carbonic Anhydrase (30,000), Trypsin Inhibitor $(20,100)$, $\alpha$ lactalbumin $(14,400)$.

A) B. asper venom from Chiriguaná, F1 to F5 separated in chromatography Sephadex G-75. FI, FII and FVII obtained in the cation-exchange chromatography Mono S.

B) Fraction F3 from the chromatography on Sephadex G-75, FIII to FVIII from cation-exchange chromatography Mono S. and B. asper venom from Chiriguaná. 
J. Ramírez-Avila et al. PURIFICATION AND PARTIAL CHARACTERIZATION OF PHOSPHOLIPASES A2 FROM Bothrops asper (BARBA AMARILLA) SNAKE VENOM FROM CHIRIGUANÁ (CESAR, COLOMBIA). J. Venom. Anim. Toxins incl. Trop. Dis., 2004, 10, 3, p.254.
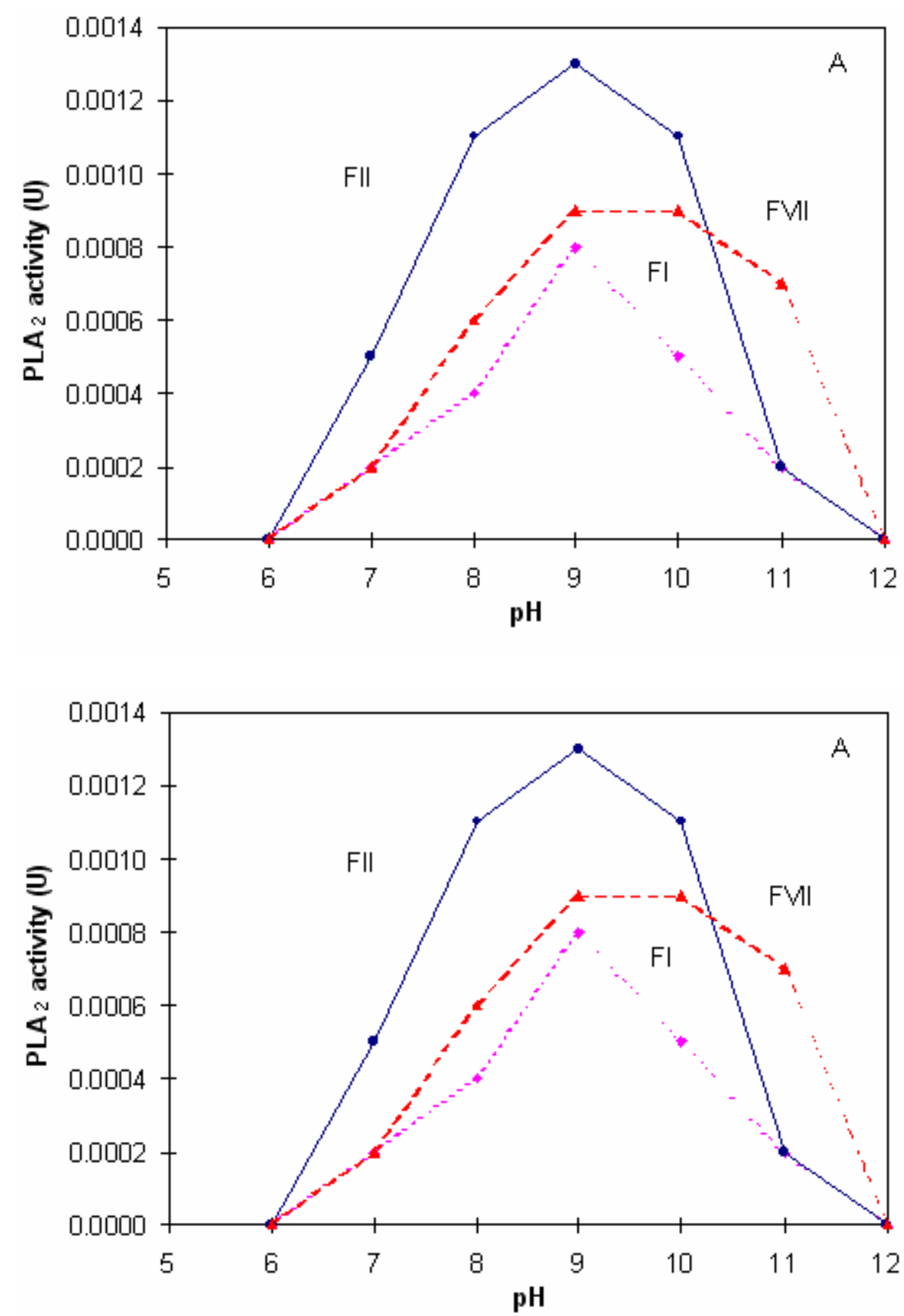

Figure 4. Effect of $\mathrm{pH}$ and temperature in the reaction velocity of the $\mathrm{PLA}_{2}$ isolated from $B$. asper venom.

PLA $_{2}$ activity was assayed by the Martin-Mountot and Rochat method (16), using an egg yolk suspension as substrate.

A) Effect of $\mathrm{pH}$ in the reaction velocity. The reaction was carried out at $25^{\circ} \mathrm{C}$ and $10 \mathrm{mM}$ of $\mathrm{CaCl}_{2} \cdot \mathrm{pH}$ was maintained constant by the addition of $5 \mathrm{mM}$ of $\mathrm{NaOH}$.

B) Effect of temperature in the reaction velocity. The reaction was carried out at $\mathrm{pH} 9$ (optimum $\mathrm{pH}$ ) and $10 \mathrm{mM}$ of $\mathrm{CaCl}_{2} \cdot \mathrm{pH}$ was maintained constant by the addition of $5 \mathrm{mM}$ of $\mathrm{NaOH}$. 


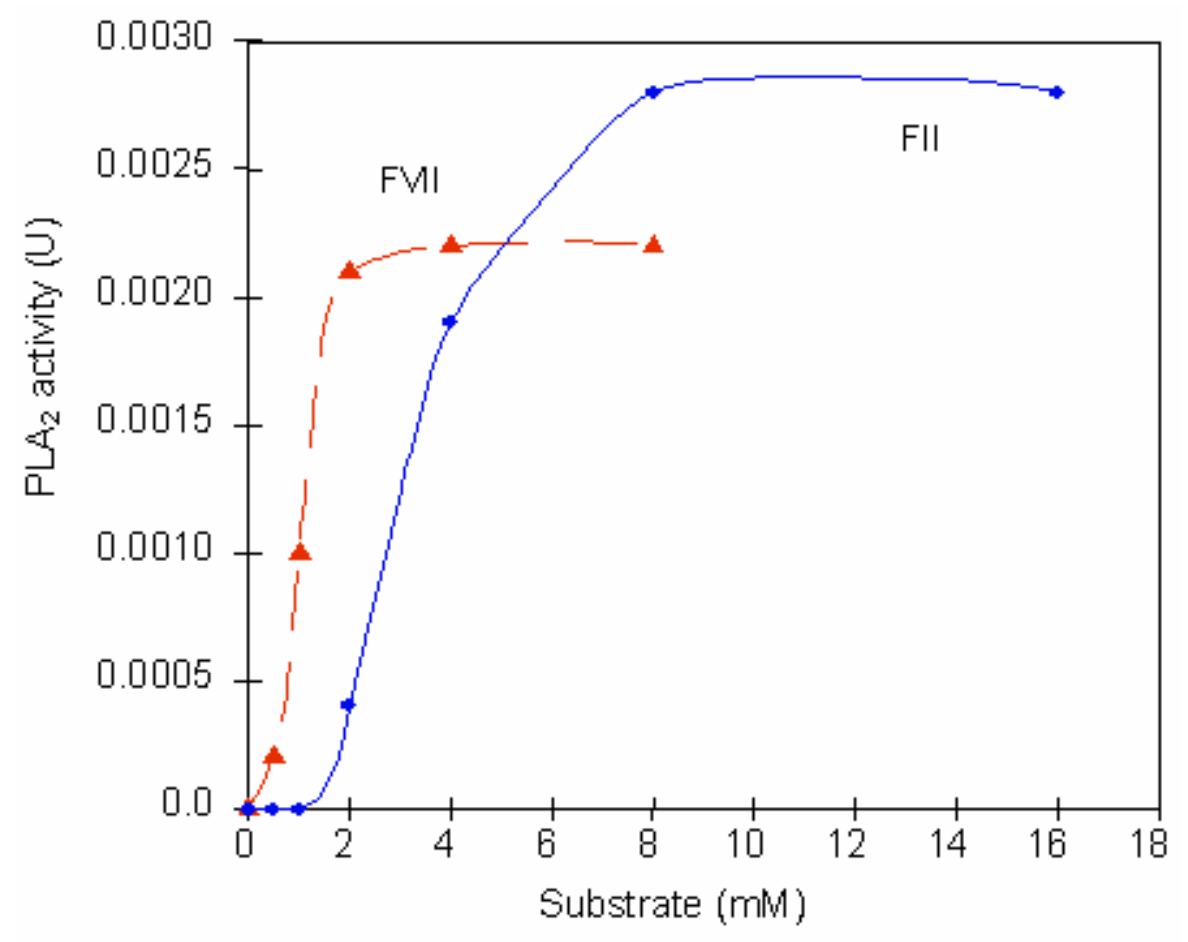

Figure 5. Effect of the substrate concentration in the reaction velocity for the two $\mathrm{PLA}_{2 \mathrm{~s}}$ isolated from B. asper venom.

$\mathrm{PLA}_{2}$ activity was assayed by the Martin-Mountot and Rochat method (16), using phosphatidylcholine isolated from egg yolk, as substrate. The reaction was carried out in optimum conditions of $\mathrm{pH}$ and temperature $\left(\mathrm{pH} 9\right.$ and $\left.52^{\circ} \mathrm{C}\right)$, and $100 \mathrm{mM}$ of calcium chloride. $\mathrm{pH}$ was maintained constant by the addition of $5 \mathrm{mM}$ of $\mathrm{NaOH}$. FII isoenzyme with continuous line (-) and FVII isoenzyme with discontinues line (---).

\section{ACKNOWLEDGEMENTS}

The authors would like to thank the personnel of Grupo de Sueros: José Arquímedes González, Luz Losada, and Dioselina Cañón for their contribution; María Cristina Forero, María Carlina Castillo, and Francisco Ruiz for their support and suggestions. Vladimir Corredor and Carlos Arturo Hernandez by the revision and comments on the manuscript. This work was supported by Instituto Nacional de Salud (INS) and Instituto Colombiano para el Desarrollo de la Ciencia y la Tecnología "Francisco José de Caldas" (COLCIENCIAS), research grant CT. 217/95. 
J. Ramírez-Avila et al. PURIFICATION AND PARTIAL CHARACTERIZATION OF PHOSPHOLIPASES A 2 FROM Bothrops asper (BARBA AMARILLA) SNAKE VENOM FROM CHIRIGUANÁ (CESAR, COLOMBIA). J. Venom. Anim. Toxins incl. Trop. Dis., 2004, 10, 3, p.256

\section{REFERENCES}

1 AGGERBECK LP., KEZDY FJ.,SCANU AM. Enzymatic probes of lipoprotein structure; hydrolysis of human serum low density lipoprotein-2 by phospholipase $\mathrm{A}_{2}$. J. Biol. Chem., 1976, 251, 3823-30.

2 CAMPBELL JA., LAMAR WW. The venomous reptiles of Latin America. New York: University Press, 1989. 425p.

3 COGO JC., PRADO-FRANCESCHI J., GIGLIO JR., CORRADO AP., CRUZ-HÖFLING MA., DONATO JL., LEITE GB., RODRIGUES-SIMIONI L. An unusual presynaptic action of Bothrops insularis snake venom mediated by phospholipase $\mathrm{A}_{2}$ fraction. Toxicon, 1998, 36, 1323-32.

4 EASTMAN KODAK COMPANY. Kodak digital science: 1D image analysis software. New York: Rochester, 1996.

5 FUJII S., IKEDA K., HAYASHI K. Catalytic and toxicity mechanisms of secretory phospholipases A2. J. Toxicol. Toxin Rev., 1998, 17, 279-313.

6 GENÉ JA., GÓMEZ M., GUTIÉRREZ JM., CERDAS L. Neutralization of hyaluronidase and indirect hemolytic activities of Costa Rica snake venoms by a polyvalent antivenom. Toxicon, 1985, 23, 1015-8.

7 GUTIÉRREZ JM., LOMONTE B. Phospholipase $\mathrm{A}_{2}$ myotoxins from Bothrops snake venoms. Toxicon, 1995, 33, 1405-24.

8 HABERMANN E., HARDT K LA Sensitive and specific plate test for the quantitation of phospholipases. Anal. Biochem., 1972, 50, 163-73.

9 IWANAGA S., SUZUKI T. Enzymes in snake venom. In: LEE CY. Ed. Snake venom handbook of experimental pharmacology. New York: Editorial Board, SpringerVerlag Berlin Heidelberg, 1979: 61-158.

10 LAEMMLI UK. Cleavage of structural proteins during the assembly of the head of bacteriophage T4. Nature, 1970, 227, 680-5.

11 LOBO DE ARAUJO A., RADVANYI F. Determination of phospholipase $\mathrm{A}_{2}$ activity by a colorimetric assay using a pH indicator. Toxicon, 1987, 25, 1181-8. 
J. Ramírez-Avila et al. PURIFICATION AND PARTIAL CHARACTERIZATION OF PHOSPHOLIPASES A 2 FROM Bothrops asper (BARBA AMARILLA) SNAKE VENOM FROM CHIRIGUANÁ (CESAR, COLOMBIA). J. Venom. Anim. Toxins incl. Trop. Dis., 2004, 10, 3, p.257

12 LOBO DE ARAUJO A., RADVANYI F., BON C. Purification of an acidic phospholipase $\mathrm{A}_{2}$ from Bothrops lanceolatus (Fer de Lance) venom: molecular and enzymatic properties. Toxicon, 1994, 32, 1069-81.

13 LOWRY OH., ROSEBROUGH NJ., FARR AL., RANDALL RJ. Protein measurement with the folin phenol reagent. J. Biol. Chem., 1951, 193, 265-75.

14 MANCUSO LC., CORREA MM., VIEIRA CA., CUNHA OAB., LACHAT JJ., SELISTRE DE ARAUJO HS., OWNBY CL., GIGLIO JR. Fractionation of Bothrops pirajai snake venom: Isolation and characterization of piratoxin-I, a new myotoxic protein. Toxicon, 1995, 33, 615-26.

15 MARAGANORE JM., MERUTKA G., CHO W., WELCHES W., KÉZDY FJ., HEINRIKSON RL. A new class of phospholipases $A_{2}$ with lysine in place of aspartate 49. Functional consequences for calcium and substrate binding. J. Biol. Chem., 1984, 259, 13839-43.

16 MARTIN-MOUTOT N., ROCHAT H. Isolation and characterization of a toxic phospholipase $\mathrm{A}_{2}$ in the spitting cobra (Naja mossambica mossambica) venom. Toxicon, 1979, 17, 127-36

17 MERRIL CR., GOLDMAN D., SEDMAN SA., EBERT MH. Ultrasensitive stain for proteins in polyaxrylamide gels shows regional variation in cerebrospinal fluid proteins. Science, 1981, 221, 1437-8.

18 NAIR BC., NAIR C., ELLIOTT WB. Temperature stability of phospholipase A $A_{2}$ activity. II. Variations in optimum temperature of phospholipase $\mathrm{A}_{2}$ from various snake venom. Toxicon, 1976, 14, 43-7.

19 OGAWA T., NAKASHIMA KI., NOBIHISA I., DESHIMARU M., SHIMAHIGASHI Y., FUKUMAKI Y., SAKAKI Y., HATTORI S., OHON M. Accelerated evolution of snake venom phospholipase $A_{2}$ isozymes for acquisition of diverse physiological functions. Toxicon, 1996, 34, 1229-36. 
J. Ramírez-Avila et al. PURIFICATION AND PARTIAL CHARACTERIZATION OF PHOSPHOLIPASES A 2 FROM Bothrops asper (BARBA AMARILLA) SNAKE VENOM FROM CHIRIGUANÁ (CESAR, COLOMBIA). J. Venom. Anim. Toxins incl. Trop. Dis., 2004, 10, 3, p.258

20 OHNO M., MÉNEZ R., OGAWA T., DANSE JM., SHIMOHIGASHI Y., FROMEN C., DUCANCEL F., ZINN-JUSTIN S., LE DU MH., BOULAIN JC., TAMIYA T., MÉNEZ A. Molecular evolution of snake toxins: Is the functional diversity of snake toxins associated with a mechanism of accelerated evolution? In: MOLDAVE K.

Ed. Progress in nucleic acid research and molecular biology. San Diego:

Academic Press, 1998: 307-64.

21 ORGANIZAÇÃO PANAMERICANA DA SAÚDE. Manual de procedimientos: producción y pruebas de control en la preparación de antisueros diftérico, tetánico, botulínico, antivenenos y de la gangrena gaseosa. 1977. 104p.

22 ROSENBERG P. Pharmacology of phospholipase $A_{2}$ from snake venoms. In: LEE CY.

Ed. Snake venom: handbook of experimental pharmacology. New York: Editorial Board, Springer-Verlag Berlin Heidelberg, 1979: 403-47.

23 SALACH JI., TURINI P., SENG R., HAUBER J., SINGER TP. Phospholipase A of snake venoms: I- Isolation and molecular properties of isoenzymes from Naja naja and Vipera russellii venoms. J. Biol. Chem., 1971a, 246, 331-9.

24 SALACH JI., SENG R., TISDALE H., SINGER T. Phospholipase A of snake venoms: IICatalytic properties of the enzyme from Naja naja. J. Biol. Chem., 1971b, 246, 340-7. 25 SLOTBOOM AJ., VERHEIJ HM., DE HASS GH. On the mechanism of phospholipases A . In: HAWTHORNE JN., ANSELL GB. Eds. Phospholipids, new biochemistry. Amsterdam: Elsevier Biomedical Press/ North Holland Press, 1982: 359-434.

26 SOARES AM., RODRIGUES VM., HOMSI-BRANDEBURGO MI., TAYOMA MH., LOMBARDI FR., ARNI RK., GIGLIO JR. A rapid procedure for the isolation of the Lys-49 myotoxin II from Bothrops moojeni (Caissaca) venom: biochemical characterization, crystallization, myotoxic and edematogenic activity. Toxicon, 1998, 36, 503-14.

27 VAN DEENEN LLM., DE HAAS GH. The substrate specificity of phospholipase A. Biochem. Physiol. Acta, 1963, 70, 538-53. 
J. Ramírez-Avila et al. PURIFICATION AND PARTIAL CHARACTERIZATION OF PHOSPHOLIPASES A 2 FROM Bothrops asper (BARBA AMARILLA) SNAKE VENOM FROM CHIRIGUANÁ (CESAR, COLOMBIA). J. Venom. Anim. Toxins incl. Trop. Dis., 2004, 10, 3, p.259

28 VILJOEN CC., BOTES DP., SCHABORT JC. Spectral properties of Bitis gabonica venom phospholipase $A_{2}$ in the presence of divalent metal ion, substrate and hydrolysis products. Toxicon, 1975, 13, 343-51.

29 VISHWANATH BS., KINI RM., GOWDA TV. Characterization of three edema-inducing phospholipase $\mathrm{A}_{2}$ enzymes from Habu (Trimeresurus flavoviridis) venom and their interaction with the alkaloid aristolochic acid. Toxicon, 1987, 25, 501-15.

30 WELCHES W., FELSHER D., LANDSHULZ W., MARAGANORE JM. A rapid method for the purification of monomer and/or dimer phospholipases $\mathrm{A}_{2}$ in crotalid snake venoms. Toxicon, 1985, 23, 747-54. 